Fountain Journal of Natural and Applied Sciences: 2015; 4(1): 35 - 46

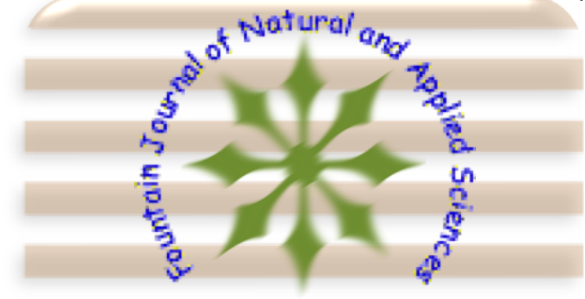

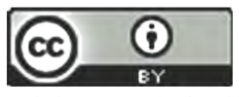

This work is licensed under Creative Commons Attribution 4.0 International License.

DOI: $10.53704 /$ fujnas.v4i1.50

A publication of College of Natural and Applied Sciences, Fountain University, Osogbo, Nigeria

Journal homepage: www.fountainjournals.com

ISSN: 2354-337X (Online), 2350-1863 (Print)

\title{
Assessment of Pollution Status around 'Awosuuru' Dump-Site, Osogbo, Nigeria.
}

\author{
Akanfe, F. A. ${ }^{1}$, Oladipo, M. A. ${ }^{2}$, Adedosu, T. A. ${ }^{2, *}$ \\ ${ }^{1}$ Department of Science Laboratory Technology, Federal Polytechnic, Ede, Nigeria \\ ${ }^{2}$ Department of Pure and Applied Chemistry, Ladoke Akintola University of Technology, Ogbomoso, Nigeria
}

\begin{abstract}
The physicochemical properties with their distribution pattern and sources of sixteen polycyclic aromatic hydrocarbons (PAHs) listed as priority pollutants were investigated in underground water, sediment and soil samples around 'Awosuuru' dump-site in Osogbo Nigeria. The physicochemical parameters; degree of acidity ( $\mathrm{pH})$, total organic carbon (TOC), Biochemical oxygen demand (BOD), and chemical oxygen demand (BOD), in the samples were determined using standard methods. The polycyclic aromatic hydrocarbons (PAHs) were analyzed quantitatively and qualitatively in the samples using gas chromatography coupled with flame ionisation detector (GC-FID). The values of $\mathrm{pH}$ and TOC ranged from 7.76 to 8.02 and 0.82 to 1.01 (wt\%) in water; 7.70 to 8.34 and 0.35 to $1.17(w+\%)$ in sediment; 8.03 to 8.56 and 0.51 to 1.05 (wt\%) in soil respectively, BOD ranged from 0.02 to $0.07(\mathrm{mg} / \mathrm{L})$ and COD from 36.40 to $64.40(\mathrm{mg} / \mathrm{L})$ in water samples. The physicochemical parameters result showed that the samples have some amount of carbonates, biodegradable and oxidizable pollutants and organic matter reflecting pollution in the study area. The concentrations of PAHs recorded in the samples indicated moderate pollution. Various diagnostic PAHs ratios indicate pyrolytic source majorly from burning of refuse. Also, the health implication of the pollution status of the study area was discussed.
\end{abstract}

Keywords: Dumpsites, GC- FID, PAHs, pollution, TOC

\section{Introduction}

Environmental Pollution has become an increasing economic and social problem for many communities around the world. Pollution is associated with the introduction of chemical compounds, solid wastes, industrial discharge, human and animal wastes and other classes of contaminants directly or indirectly into the environment, resulting in harmful effect of such a nature as to endangered human health, harms living resources and interferes with other legitimate use of the environment (Amokaye, 2012). Pollutant levels become unacceptable when they result in detrimental changes to an organism or the biological community (Kruczynski, 2002). The greatest danger to the quality of our environment is posed by human activities. Man in search for development and development and comfort has launched into industrial revolution

*Corresponding author: +234-7055302824

Email address: taadedosu@lautech.edu.ng 
had resulted in the development of various industrial sectors. The development of various industries and urbanization are accompanied by the introduction of different classes of contaminants into the environment (air, water and soil) which seriously damaging its natural processes (Solomon et al., 2007). Environmental pollution due to the inability to manage increasing wastes generated from industries, urbanization, exploration of natural resources and modern agricultural practices is a major concern in most developing counties including Nigeria (McMichael, 2000). In highly populated cities rapid urbanization lead to increasing indiscriminate discharge of sewage and solid wastes (Saad et al., 1994; Adekola et al., 2003; Midodo and Orosanya, 2006). Most cities lack proper waste disposal facilities, heaps and accumulation of waste are seen in streets and open dumpsites (Ngigwe, 2008). Water bodies are one of the highly polluted environmental media (Adeyemo, 2003), water bodies are polluted due to runoff of these wastes into the water bodies, leaching of pollutant into groundwater and discharge of industrial effluents into the water bodies. The quality of any water body is governed by its physicochemical parameters. Water quality monitoring has a high priority for the determination of current conditions and long term trends for effective management of water bodies (Arian et al., 2008). The assessment of physicochemical characteristics of water body is vital for both long term and short time evaluation of its quality. Physicochemical parameters such as Dissolved oxygen (DO) determination help to assess the raw water quality and to keep check on stream pollution.

Dissolved Oxygen, DO is the basis of Biochemical oxygen demand, BOD which is an important parameter in evaluating the pollution potential of domestic and industrial wastes. This might be due to the use of chemicals which are organic or inorganic and are oxygen demand (DWARF, 1996). The chemical oxygen demand (COD) is a measure of the oxygen equivalent of that portion of organic matter in a sample that is susceptible to oxidation by a strong chemical oxidant (strong oxidising agents). High COD levels indicate toxic state of the waste waters along with presence of biologically resistant organic substances (Sawyer and McCarty, 1998).

Persistent organic and inorganic pollutants including Polyaromatic hydrocarbons, phthalate esters, pesticides and polychlorinated biphenyls and heavy metals have also been detected in water samples. Polycyclic aromatic hydrocarbons (PAHs) are known to enter environments through industrial discharges, petroleum spills, combustion of fuels, automobile exhausts, and non-point sources such as urban run- off and atmospheric fall out (Chen et al., 2004; Yang et al., 2014). They are neutral, non-polar, organic molecules which consist of two or more condensed benzene rings interconnected in different combinations with hydrophobicity which increases with the molecular weight. PAHs of petrogenic origin, prevalent in coals and fossil fuels, are formed from diagenesis of sedimentary organic material under low to moderate temperature and tend to consist of low molecular-weight PAHs with two to three aromatic rings while the pyrolytic PAHs consist mainly of four or more aromatic rings. The aim of this study is to determine some physicochemical parameters and level of polycyclic aromatic hydrocarbons (PAHs) in water, sediment and soil around Awosuuru dumpsite in Osogbo, Nigeria and to evaluate the associated health risk.

\section{Materials and Methods \\ Study Area and Sample collection}

'Awosur' dumpsite is located in Osogbo, southwest Nigeria. It is located about $300 \mathrm{~m}$ to the main road in Awosuuru along Iwo - Osogbo Road, Figure 1 show the location of the dumpsite. It is an open dumpsite receiving most of the solid waste within the area. Waste are dumped in the site without proper treatment and burnt. A stream flows beside the dumpsite transporting the solid dumps and leachates from the dumpsites to the surface water bodies and soil around the area. Soil, water and sediments samples were collected around the 'Awosuru' dumpsite located in Osogbo Nigeria. The sampling point coordinates 
are as shown in table 1. Surface layer of soil samples $(1-10 \mathrm{~cm})$ and the stream sediment samples were collected from the dumpsite area. Samples were hand dug with a hand trowel that was cleaned prior to use and between samples.

The soil and stream sediment samples were collected into metal plates lined with aluminium foil. Water samples were collected into $250 \mathrm{ml}$ amber bottles and were stored in the refrigerator at $4{ }^{\circ} \mathrm{C}$ before analysis. The soil and sediment samples were air dried and sieved with a sieve of $200 \mu \mathrm{m}$ openings and stored in amber bottles.

\section{Determination of Water physicochemical Parameters}

The dissolved oxygen content of the water samples were determined before and after five days incubation at $20{ }^{\circ} \mathrm{C}$. The BOD is calculated on the basis of oxygen depleted. The $\mathrm{pH}$ of the samples was determined in-situ using the $\mathrm{pH}$ meter with digital voltmeter scale for direct $\mathrm{pH}$ measurement. The total organic carbon (TOC) was deterrmined using Walkley-Black procedure (Walkley-Black 1934).

\section{Analysis of PAHs}

$10 \mathrm{~g}$ each of sample (soil and sediments) was weighed with $10 \mathrm{~g}$ each of anhydrous sodium sulphate and grounded into free flowing powder.
Each sample was ultrasonically extracted with $30 \mathrm{ml}$ acetone-hexane $(1: 1, \mathrm{~V} / \mathrm{V})$ for $20 \mathrm{~min} .200 \mathrm{ml}$ of the water sample was transferred into a $1 \mathrm{~L}$ separating funnel and $60 \mathrm{ml}$ of the redistilled dichloromethane was added. The separating funnel was shaken vigorously for about $2 \mathrm{~min}$. with periodic venting to release vapour pressure. The organic layer was allowed to separate for $10 \mathrm{~min}$ and was recovered into $250 \mathrm{ml}$ flask. The aqueous layer was re-extracted twice with $60 \mathrm{ml}$ of redistilled dichloromethane. The combined extract was dried by passing through the funnel containing the anhydrous sodium sulphate. The dried extract was concentrated with a stream of nitrogen gas. The concentrated extract was cleaned up in a column (30 $\mathrm{cm} \times 10 \mathrm{~mm}$ i.d.) packed with silica gel/alumina (4:1). The column was preeluted with $30 \mathrm{ml}$ of hexane before loading the sample. The concentrated extract was separated into saturate, aromatic (PAHs) and polar fractions by using $30 \mathrm{ml}$ of $\mathrm{n}$ - hexane, $30 \mathrm{ml}$ of $\mathrm{n}$-hexane / dichloromethane $(2: 3, \mathrm{v} / \mathrm{v})$ and $30 \mathrm{ml}$ of methanol respectively. The PAH fraction was subjected to gas chromatographic analysis. Aliquot of $\mathrm{PAH}$ fraction was injected into a gas chromatography HP 5890 powered with HPCMEM software with flame ionization detector (FID). The separation was effected on $30 \mathrm{~cm} \times 0.25 \mathrm{~mm}$ i.d., HP-5 fused silica column using nitrogen as carrier gas. The oven temperature ramped at $100{ }^{\circ} \mathrm{C}$ ( $2 \mathrm{~min}$ hold)

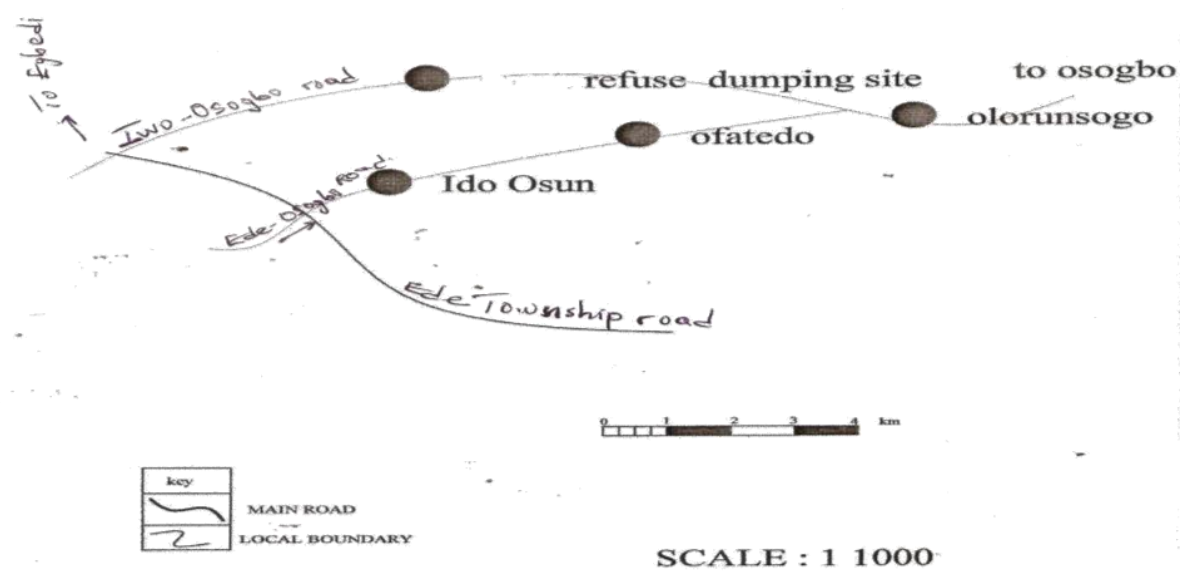

Figure 1: Awosuuru Dumpsite showing soil sampling sites 
followed by $280{ }^{\circ} \mathrm{C}$ for $16 \mathrm{~min}$ at $10{ }^{\circ} \mathrm{C} / \mathrm{min}$, then $300{ }^{\circ} \mathrm{C}$ for $4 \mathrm{~min}$ and $10{ }^{\circ} \mathrm{C} / \mathrm{min}$. The USEPA 16 priority PAHs standard mix was analyzed using the same instrumental conditions. The identification of PAHS was by comparison of samples retention times with that of the USEPA standard mix. The quantification was performed using external calibration method based on five point's calibration curves for the standard PAHS mix.

For quality control, all solvents used for the analysis were high purity analytical grade, recovery studies was carried out by spiking samples of known concentration of PAHs with PAH mix standard of known concentrations and analysed by the test method. Two methods blanks (solvents) were also analysed along with the field samples. The concentrations of the PAHs in the method blanks are below the method detection limit.

\section{Data Analysis}

The concentration of the PAHs in the soil and sediments samples were presented based on the dry weight equvalent of the samples. The total concentration of the PAHs are based on the sum of the sixteen United State Environmental Protection Agency, USEPA priority PAHs. To aseess the potential ecotoxicity and health risk due to the presence of PAHs in the soil, water and sediments samples, the percentage concentration of carcinogenic and mutagenic PAHs were calculated from the average concentrations of induvidual PAHs from each sample. The cacinogenic and mutagenic potency were also calculated by mutiplying the average concentration of PAHs with the Bap-toxicity equvalent factors and with Bap-mutagenic equvalent factors proposed by Nisbet and Lagoy, 1992; Busby et al., 1996). Diagnostic ratios of PAHs are employed to identify the sources of the PAHs in the samples, the values of anthracene lanthracene+phenanthrene, (Ant/(Ant+Phe), phenanthrene/anthracene, (Phe/Ant), fluoranthene/pyrene (Flu/Pyr) and Benzo(a)pyrene/(Benzo(a)pyrene + chyresne) ratio have been used extensively to distinguish between petroleum and combustion sources of PAHs. The value of Phe/Ant greater than 10 and Flu/pyr less than 1 suggest petrogenic origin and value between 1.0 - 1.4 indicates biomass and coal combustion source, Ant/(Ant+Phe) less than 1 is an indication of petroleum origin while less than 0.1 indicates combustion source (Yunker et al., 2002: Huang et al., 2003). Also, the value of $\mathrm{Flu} /(\mathrm{Flu}+\mathrm{Pyr}$ ) less than 0.4 indicates petrogenic source, and 0.4- 0.5 pyrogenic source and greater than 0.5 indicates combustion of biomass (Yunker et al., 2002; Chen et al., 2005). Furthermore, benzo(a)anthracene/(benzo(a)anthracene + chrysene $)(\mathrm{BaA} /(\mathrm{BaA}+\mathrm{Chr}))$ of 0.35 andideno(123-cd)pyrene/ideno(123-cd) pyrene + benzo(ghi)perylene (Icdp/(Icdp + Bghip)) of 0.5 mark the transition point of the petroleum and combustion sources. Specifically, $\mathrm{BaA} /(\mathrm{BaA}+\mathrm{Chr})$ $<0.2$, between 0.2-0.35 and $>0.35$ indicates mainly petroleum input, inputs from both sources and combustion input, respectively. Likewise, Icdp/(Icdp + Bghip) greater 0.2, between 0.2-0.5 and more than 0.5 infers petroleum input, liquid fossil fuel combustion and grass, wood and coal combustion, respectively (Yunker et al., 2002).

\section{Results and discussion}

\section{Physicochemical parameters}

The $\mathrm{pH}$, total organic carbon, biochemical oxygen demand and chemical oxygen demand of the samples were determined, the results of the physicochemical parameters were presented in Table 1. The $\mathrm{pH}$ of the water samples ranged between 7.76 and 8.02 with a mean value of 7.88 , soil between 8.02 and 8.56 and sediment between $7.70-8.12$. the $\mathrm{pH}$ of an aquatic ecosystem is an important indicator of water quality, the $\mathrm{pH}$ of the water samples and the sediments shows alkalinity in its value. The mean $\mathrm{pH}$ value of the water samples is higher than the recommended $\mathrm{pH}$ range for portable water. The World Health organization, WHO acceptable $\mathrm{pH}$ value for portable water was 6.8 and 7.4 (DWARF, 1996; Akan et al., 2008). The chemical oxygen demand is a measure of the oxygen equivalent of the organic 
Fountain Journal of Natural and Applied Sciences: 2015; 4(1): 35 - 46

Table 1: Physicochemical parameters of the samples

\begin{tabular}{|c|c|c|c|c|c|}
\hline Sample & Location & BOD (mg/L) & $C O D(\mathrm{mg} / \mathrm{L})$ & $\mathrm{pH}$ & TOC (wt \%) \\
\hline$O S w_{1}$ & $\mathrm{~N} 07^{\circ} 46^{\prime} .25 \mathrm{E} 004^{\circ} 32^{\prime} .28$ & $0.07 \pm 0.02$ & $36.40 \pm 12.20$ & $7.76 \pm 0.06$ & $1.01 \pm 0.01$ \\
\hline $\mathrm{OSW}_{2}$ & $\mathrm{~N} 07^{\circ} 46^{\prime} .26 \mathrm{E} 004^{\circ} 32^{\prime} .29$ & $0.06 \pm 0.015$ & $64.40 \pm 10.59$ & $7.85 \pm 0.05$ & $0.97 \pm 0.07$ \\
\hline $\mathrm{OSW}_{3}$ & $\mathrm{~N} 07^{\circ} 46^{\prime} .24 \mathrm{E} 004^{\circ} 32^{\prime} .27$ & $0.02 \pm 0.015$ & $45.20 \pm 10.43$ & $8.02 \pm 0.02$ & $0.82 \pm 0.02$ \\
\hline OSsoil $_{1}$ & $\mathrm{~N} 07^{\circ} 47^{\prime} .60 \mathrm{E} 004^{\circ} 29^{\prime} .35$ & ND & ND & $8.03 \pm 0.03$ & $1.05 \pm 0.03$ \\
\hline OSsoil $_{2}$ & $\mathrm{~N} 07^{\circ} 47^{\prime} .64 \mathrm{E} 004^{\circ} 29^{\prime} .05$ & ND & ND & $8.56 \pm 0.06$ & $0.70 \pm 0.05$ \\
\hline OSsoil $_{3}$ & $\mathrm{~N} 07^{\circ} 47^{\prime} .61 \mathrm{E} 004^{\circ} 29^{\prime} .65$ & ND & ND & $8.34 \pm 0.04$ & $0.51 \pm 0.02$ \\
\hline OSsed $_{1}$ & $N 07^{\circ} 46^{\prime} .25 \mathrm{E} 004^{\circ} 32^{\prime} .28$ & ND & ND & $7.70 \pm 0.10$ & $0.35 \pm 0.35$ \\
\hline OSsed $_{2}$ & $\mathrm{~N} 07^{\circ} 46^{\prime} .26 \mathrm{E} 004^{\circ} 32^{\prime} .29$ & ND & ND & $7.85 \pm 0.05$ & $0.86 \pm 0.86$ \\
\hline OSsed $_{3}$ & $N 07^{\circ} 46^{\prime} .24$ E $004^{\circ} 32^{\prime} .27$ & ND & ND & $8.12 \pm 0.02$ & $1.17 \pm 1.17$ \\
\hline
\end{tabular}

OSw - Osogbo water sample; OSsoil - Osogbo soil; OSsed - Osogbo sediment; ND - Not Determined; BOD-Biochemical Oxygen Demand; COD-Chemical Oxygen Demand

Table 2.0 concentration of PAHs in soil, water and sediments $(\mu \mathrm{g} / \mathrm{kg})$

\begin{tabular}{|c|c|c|c|c|c|c|c|c|c|}
\hline PAH & OS soil & $\mathrm{OSSOil}_{2}$ & $\mathrm{OSsoil}_{3}$ & OS sed 1 & $\mathrm{OS} \mathrm{sed}_{2}$ & $\mathrm{OSsed}_{3}$ & $O S w_{1}$ & $\mathrm{OSW}_{2}$ & $\mathrm{OSW}_{3}$ \\
\hline Naphthalene & 0.1455 & 0.1462 & 0.1043 & 0.0641 & 0.0657 & 0.0745 & 0.0305 & 0.0241 & 0.0675 \\
\hline Acenaphthylene & 2.3928 & 1.3777 & 1.7453 & 0.5538 & 0.7574 & 0.7294 & 0.9682 & 0.7554 & 0.8148 \\
\hline Acenaphthene & 1.3264 & 1.3978 & 1.2146 & 0.5649 & 0.7167 & 0.7199 & 0.7129 & 0.5769 & 0.7516 \\
\hline Fluorene & 2.5293 & 2.6516 & 1.7445 & 1.0730 & 1.8793 & 1.3661 & 0.7154 & 0.5620 & 0.6165 \\
\hline Phenanthrene & 2.4430 & 2.5220 & 1.6293 & 1.0344 & 1.7978 & 1.2927 & 0.9010 & 0.7879 & 0.8036 \\
\hline Anthracene & 1.3116 & 1.3665 & 1.0222 & 0.5580 & 0.5346 & 0.7165 & 0.9153 & 0.6877 & 0.8830 \\
\hline Fluoranthene & 1.6634 & 1.6688 & 1.9763 & 0.6763 & 0.7119 & 0.8176 & 0.4842 & 0.4667 & 0.5811 \\
\hline Pyrene & 0.9282 & 0.9288 & 0.8978 & 0.3992 & 0.3123 & 0.4839 & 0.9935 & 0.8967 & 0.6014 \\
\hline Benzo(a)anthracene & 1.8332 & 1.8470 & 2.1148 & 0.8188 & 0.8012 & 0.9558 & 0.6496 & 0.8640 & 0.9691 \\
\hline Chrysene & 1.4440 & 1.4675 & 1.6736 & 0.6341 & 0.6782 & 0.7479 & 0.2198 & 0.6182 & 0.6310 \\
\hline Benzo(b)fluoranthene & 0.2158 & 0.8147 & 0.3748 & 0.0950 & 0.0188 & 0.1096 & 0.1121 & 0.0408 & 0.0435 \\
\hline Benzo(k)fluoranthene & 0.0638 & 1.4324 & 0.5954 & 0.02947 & 0.0124 & 0.0348 & 0.0602 & 0.0238 & 0.0172 \\
\hline Benzo(a)pyrene & 6.8832 & 16.9162 & 5.9521 & 2.9260 & 2.95186 & 3.5805 & 0.0021 & 0.0088 & 0.0230 \\
\hline Indeno(1,2,3-cd)pyrene & 1.7966 & 1.8396 & 1.6159 & 0.8222 & 0.7648 & 0.9237 & 0.0034 & 0.0016 & 0.0049 \\
\hline Dibenzo(a,h)anthracene & 0.7877 & 0.7517 & 0.3252 & 0.3620 & 0.1295 & 0.3596 & 0.0002 & 0.0004 & 0.0016 \\
\hline Benzo(g,h,i)Perylene & 0.2301 & 0.2375 & 0.0825 & 0.1092 & 0.4527 & 0.1161 & 0.0002 & 0.0001 & 0.0010 \\
\hline$\Sigma 16 E P A$ & 25.9966 & 37.3660 & 23.0686 & 10.7204 & 12.5852 & 13.0286 & 6.7686 & 6.3151 & 6.8108 \\
\hline Mean & 1.6248 & 1.7104 & 1.3931 & 0.6700 & 0.7866 & 0.8143 & 0.4230 & 0.4369 & 0.4257 \\
\hline$\Sigma L M W$ PAH & 10.1486 & 9.4618 & 7.4602 & 3.8482 & 5.7515 & 4.8991 & 4.2433 & 3.394 & 3.937 \\
\hline$\Sigma \mathrm{HMW}$ PAH & 15.846 & 27.9042 & 15.6084 & 6.87227 & 6.83366 & 8.1295 & 2.5253 & 2.9211 & 2.8738 \\
\hline
\end{tabular}

$\Sigma 16 E P A=$ total concentration of 16 EPA PAHs; $\Sigma L M W$ PAH = total concentration of low molecular weight PAHs, $\Sigma H M W P A H=$ total concentration of high molecular weight PAHs.

matter content of the sample that is susceptible to oxidation by strong chemical oxidants. The value of the chemical oxygen demand of the water sample ranged between $36.40 \mathrm{mg} / \mathrm{L}$ to $64.40 \mathrm{mg} / \mathrm{L}$. The COD values show that all the water samples are polluted. The Total Organic Carbon, TOC value in the water samples ranged between 0.82 - 1.01, soil between $0.51-1.05$ and sediments between $0.35-1.17$. TOC values show that the samples contain significant amount of 
organic pollutants one of which could be polycyclic aromatic hydrocarbons (Sunita and Sumanjeet 1999).

Occurrence and Spatial Distribution of Polyaromatic hydrocarbons

The concentrations of the 16 PAHs, sum of which is defined as $\Sigma 16 P A H s$ are presented in Table 2.0. The concentrations of the I16PAHs in soil samples were the highest, the concentration
Of PAHs in the soil sample ranged from $23.068 \mu \mathrm{g} / \mathrm{kg}$ to $37.366 \mu \mathrm{g} / \mathrm{kg}$ with a highest mean concentration of $1.7104 \mu \mathrm{g} / \mathrm{kg}$ (Table 2). Organic pollutants accumulates in the water sediments and the concentration of $\Sigma 16 \mathrm{PAH}$ in the sediment samples are higher than that of the water samples, the $\Sigma 16 \mathrm{PAH}$ in the sediment and water samples ranged from $10.7204 \mu \mathrm{gg} / \mathrm{kg}$ to 13.0286 $\mu \mathrm{g} / \mathrm{kg}$ and $6.3151 \mu \mathrm{g} / \mathrm{kg}$ to $6.8108 \mu \mathrm{g} / \mathrm{kg}$ respectively. The mean concentrations of the

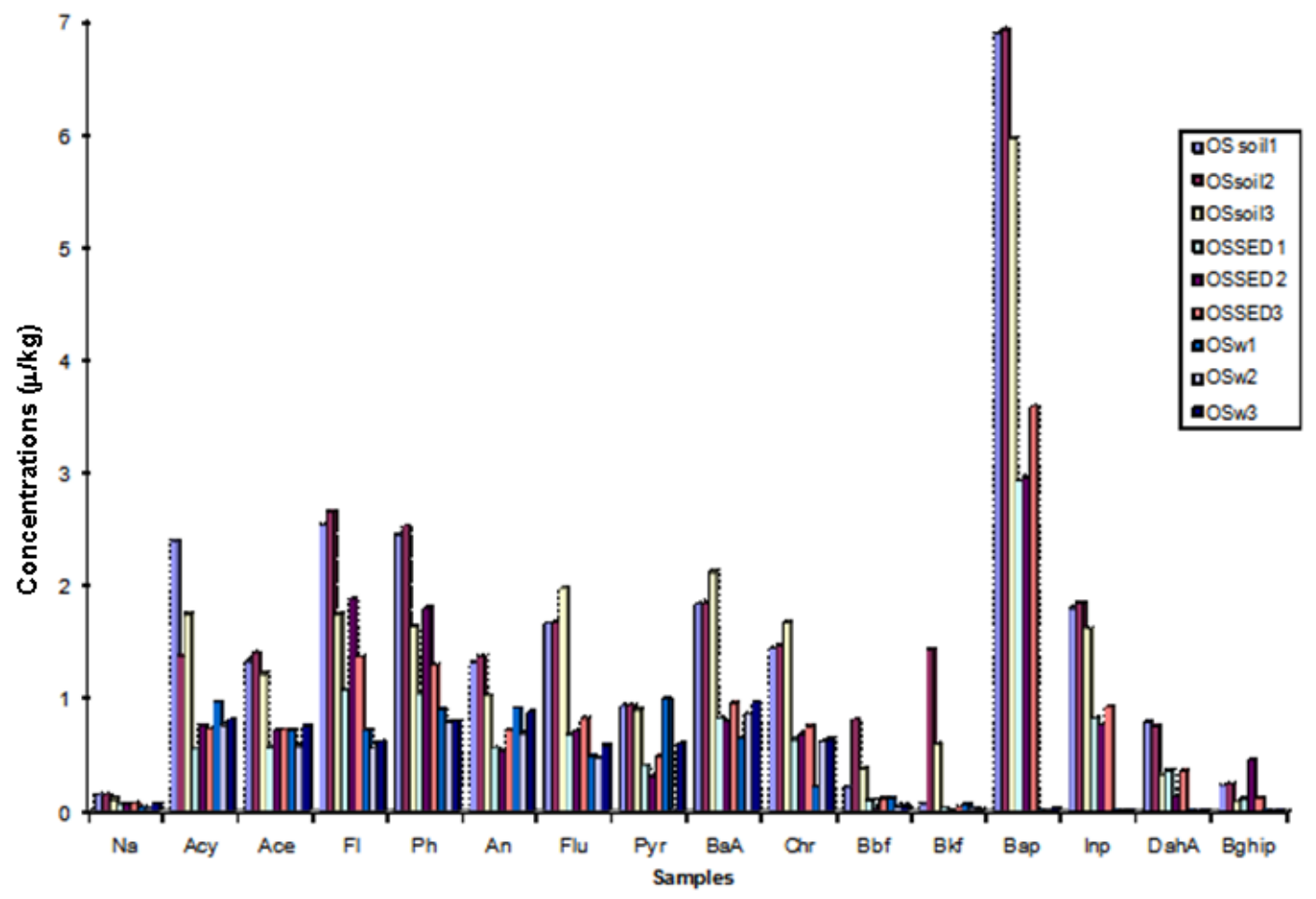

Figure 2: Distribution of individual PAHs at different locations

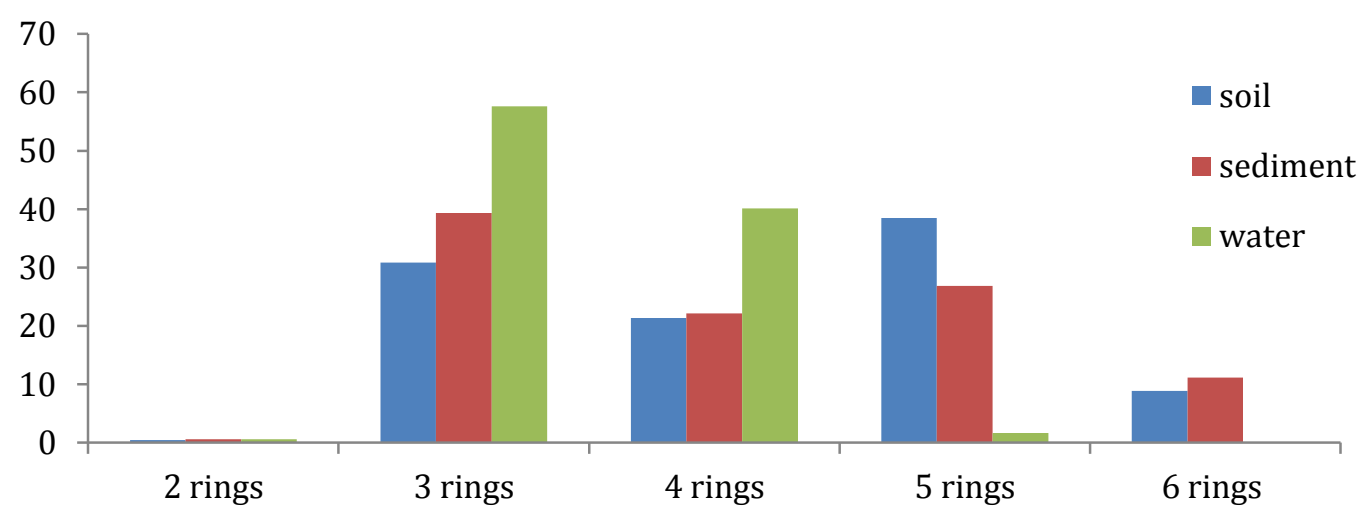

Figure 3: Percentage ring size distribution of PAHs in the soil, sediments and water samples 
PAHs in the dumpsite soil are higher than that of the sediments and the surface water samples. The total concentration of high molecular weight PAHs, $\Sigma$ HMPAHs in all the soil and sediments samples are higher than the total concentrations of the low molecular weight PAHs, LLMWPAHs, the percentage concentration of $\Sigma L M W P A H s$ is $31.32 \%, 39.91 \%$ and $58.18 \%$ in soil, sediment and water respectively and the percentage concentration of $\Sigma$ HMPAHs $68.86 \%, 60.09 \%$ and $58.18 \%$ respectively. A marked distribution pattern of the PAHs concentration in the samples was apparent, 1-,2-,3-,4-,5- and 6- ring size PAHs are detected in all the water, soil and sediments samples with predominance of 3-,5- and 4- ring size PAHs in the soil and sediment samples and predominance of 3- and 4- ring size PAHs in the water samples, the 3- and 4- rings size PAHS

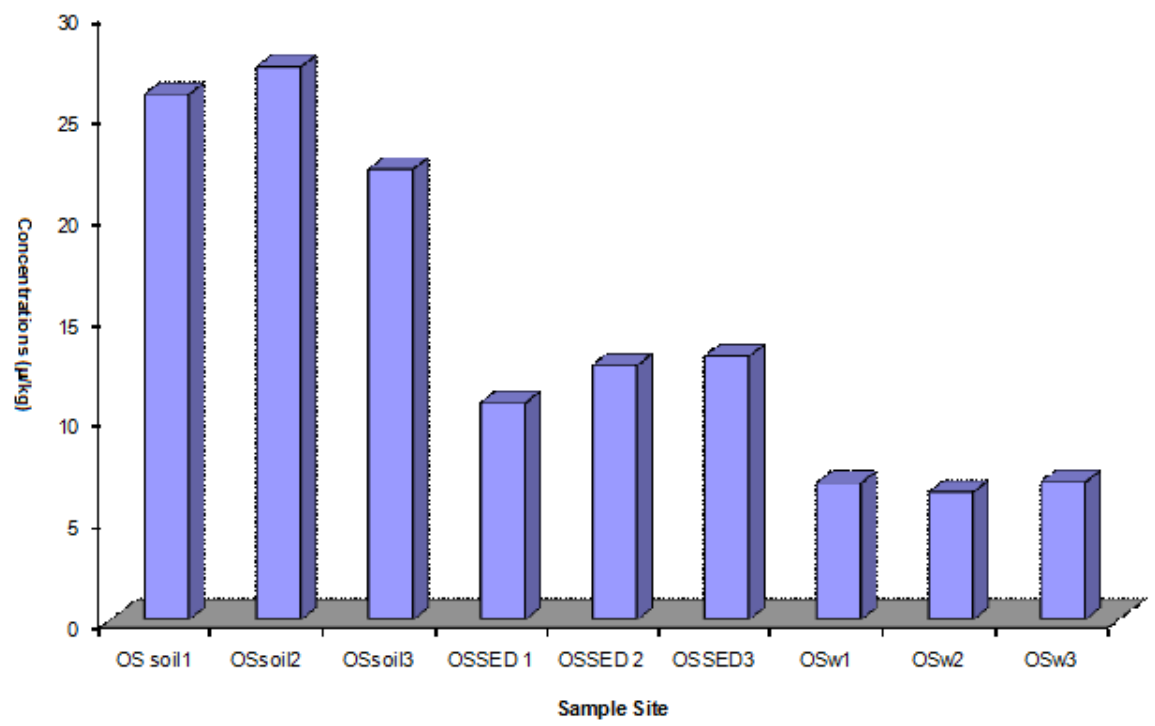

Figure 4: Relative distributions of PAHs at different locations

Table 3: Relative distribution pattern $(\mu \mathrm{g} / \mathrm{kg}$ ) and percentage composition of individual PAHs in the samples

\begin{tabular}{|c|c|c|c|c|c|}
\hline $\begin{array}{l}\text { Samples } \\
\text { Soil }\end{array}$ & 2 rings & 3 rings & 4 rings & 5 rings & 6 rings \\
\hline Os soil & 0.145480 & 8.00305 & 5.868733 & 1.06940 & 2.02669 \\
\hline Os soil 2 & 0.146150 & 9.31548 & 5.912217 & 9.91502 & 2.07708 \\
\hline Ossoil $_{3}$ & 0.104338 & 7.35580 & 6.66220 & 7.24786 & 1.69828 \\
\hline Total & 0.3960 & 24.6743 & 18.4426 & 18.2323 & 5.8021 \\
\hline$\%$ & 0.59 & 36.53 & 26.99 & 26.99 & 8.99 \\
\hline \multicolumn{6}{|l|}{ Sediment } \\
\hline Os sed d $_{1}$ & 0.0640867 & 3.28175 & 2.34701 & 0.17455 & 0.003523 \\
\hline Os sed 2 & 0.065671 & 5.68579 & 2.84524 & 0.07383 & 0.001695 \\
\hline Os sed 3 & 0.0744679 & 4.824664 & 2.78264 & 0.08527 & 0.00586 \\
\hline Total & 0.2042 & 13.7922 & 7.9749 & 0.3337 & 0.0111 \\
\hline$\%$ & 0.59 & 40.03 & 40.12 & 1.68 & 0.06 \\
\hline \multicolumn{6}{|l|}{ Water } \\
\hline$O s w_{1}$ & 0.0304759 & 4.21281 & 2.34701 & 0.17455 & 0.003523 \\
\hline Os $w_{2}$ & 0.0240628 & 3.35397 & 2.84524 & 0.07383 & 0.001696 \\
\hline $\mathrm{Os} \mathrm{w}_{3}$ & 0.674808 & 3.8695 & 2.78264 & 0.08527 & 0.00586 \\
\hline Total & 0.1220 & 11.4363 & 7.9749 & 0.3337 & 0.0111 \\
\hline$\%$ & 0.61 & 57.53 & 40.12 & 1.68 & 0.06 \\
\hline
\end{tabular}


accounted for approximately $57.56 \%$ and $40.09 \%$ of the $\Sigma 16 \mathrm{PAH}$ in all the water samples (figure 2). The 5-rings PAHS accounted for $38.47 \%$, $26.85 \%$ and the 3 - rings PAHs $30.86 \%, 39.34 \%$ of the $\Sigma 16 \mathrm{PAH}$ in the soils and sediments samples respectively. The levels of $\Sigma 16$ PAHs in the soil and sediment samples are lower than those reported for soils from other parts of the world (Table 4) (Sojinu et al., 2010). The total concentrations of Beijing urban soil ranged from 467 to $5,470 \mu \mathrm{g} / \mathrm{kg}$ and also five cities(Tallinn, Helsinki, Vilnus, Chicago, and London) urban soils had a concentration of $1090 \mu \mathrm{g} / \mathrm{kg}$ (mean value). For sediment, the total concentration of England and Wales is $102,000 \mu \mathrm{g} / \mathrm{kg}$. While for water, the total concentration of PAH in yellow river, China, ranged from $31 \mu \mathrm{g} / \mathrm{kg}$ to $133 \mu \mathrm{g} / \mathrm{kg}$. For water samples, comparison of the concentration of some PAHs in the study area with the Canadian and Netherlands guidelines for water analysis shows that the water samples under study are polluted (Table 5).

\section{Source Diagnostic Ratios}

The source diagnostic indices are calculated from interpretative $\mathrm{PAH}$ concentrations and presented in Tables 6 . The values of these ratios were used to indicate source of the PAHs (Sojinu et al., 2010; Adedosu et al., 2013). The Ph/An ratio ranged from 0.91 to $1.15,1.80$ to 3.36 and 1.59 to 1.86 in water, sediment and soil respectively, this values are less than 10 and indicates pyrogenic sources of PAHs in the samples (Adedosu et al., 2013). The value of the Flu/Pyr ratio ranged from 0.61 to $1.03,2.69$ to 6.02 and 1.94 to 2.86 in water, sediment and soil respectively. This value suggested a pyrogenic source of PAHs mostly from combustion of biomass and Bap/Chr ratios ranged from 1.40 to $2.96,1.18$ to 1.28 and 1.26 to 1.27 in water, sediment and soil respectively. These ratios are higher than 1 but lesser than 10 in all the samples, therefore indicating pyrolytic source. The range of values of $\mathrm{Nap} / \mathrm{Ace}, \mathrm{An} / \mathrm{Ph}+\mathrm{An}$, Flu/Flu + Pyr, BaA/BaA + Chr and InP /InP + Bghip are lesser than 1 in all the samples thus indicating pyrolytic source.

\begin{tabular}{|c|c|c|c|}
\hline Location & No of PAHs & PAHs $(\mu \mathrm{g} / \mathrm{kg})$ & Source type \\
\hline \multicolumn{4}{|l|}{ Soils } \\
\hline Beijing, China & 16 EPA & $467-5,470$ & Urban soils \\
\hline Canada & 17 & 1,400 & Highway \\
\hline U.K & 07 & 20,000 & Motorway \\
\hline U.S & 14 & 3,000 & Highway \\
\hline Australia & 18 & $300-79,000$ & Chemical plant \\
\hline Japan & 08 & $1300^{a}$ & Urban soils \\
\hline U.K. & 16 & $2,700^{a}$ & Urban soils \\
\hline New Oleans (U.S) & 16 & 3,730 & Urban soils \\
\hline W. Macedonian (Greece) & 16 & $55.2-495$ & Lignite fire plant \\
\hline Linz(Austria) & 18 & $1450^{a}$ & Industrial area \\
\hline Zeizate(Belgium) & 07 & $3,000-14,000$ & $1.3-4.2 \mathrm{~km}$ from an Oil refinery \\
\hline $\begin{array}{l}\text { Five cities (Tallinn, Helsinki, } \\
\text { Vilnius, Chicago\& London) }\end{array}$ & 16 & $1,090^{a}$ & Urban soils \\
\hline Novi Sad (Serbia \& & 16 & $47,900^{a}$ & Oil refinery \\
\hline \multicolumn{4}{|l|}{ Montenegro) } \\
\hline Tokushima (Japan) & 13 & $611^{a}$ & Urban soils \\
\hline Niger Delta, Nigeria & 28 & $23.8-120$ & Close to oil Installations \\
\hline \multicolumn{4}{|l|}{ Sediments } \\
\hline England \&Wales & 16EPA & 102,000 & Surface \\
\hline Thailand & 14 & $6-8,400$ & Surface \\
\hline Yellow river, China & 13 & $31-133$ & Surface \\
\hline Niger Delta, Nigeria & 28 & $65-331$ & Close to oil installations \\
\hline
\end{tabular}

\footnotetext{
a Menn values
} 
Fountain Journal of Natural and Applied Sciences: 2015; 4(1): 35 - 46

Table 5: Comparison of the Concentration of some Selected PAHs in water samples from the Study Area with the Canadian and Netherlands Guidelines for water analysis ( $\mu \mathrm{g} / \mathrm{kg})$

\begin{tabular}{llll}
\hline PAHs & Mean Concentration & $\begin{array}{l}\text { Canadian (2008) mean } \\
\text { concentration }\end{array}$ & $\begin{array}{l}\text { Netherlands(2008) } \\
\text { mean concentration }\end{array}$ \\
\hline Nap & 0.0467 & 0.00011 & NA \\
Ace & 0.6804 & 0.00058 & 0.0012 \\
Flu & 0.0300 & 0.0003 & 0.00007 \\
Ant & 0.8287 & 0.000012 & 0.00007 \\
Phe & 0.0300 & 0.0004 & 0.0003 \\
Fla & 0.5107 & 0.00004 & 0.0003 \\
Pyr & 0.8306 & 0.000025 & $\mathrm{NA}$ \\
Chr & 0.0300 & $\mathrm{NA}$ & 0.00034 \\
B[a]A & 0.0300 & 0.000018 & 0.00001 \\
B[a]P & 0.0300 & 0.000015 & 0.00005 \\
Bkf & 0.0337 & $\mathrm{NA}$ & 0.00004 \\
B[ghi]P & $\mathrm{NA}$ & 0.000033 & 0.00006 \\
\hline
\end{tabular}

NA: Not Available

Table 6: Molecular indices of PAHs in the samples

\begin{tabular}{lllllllll}
\hline Sample & Ph/An & Flu/Pyr & Bap/Chr & Nap/Ace & An/(Ph+An) & Flu/(Flu + Ph) & BaA/(BaA+ Chr) & InP/(Inp + Bghip) \\
\hline OSsoil $_{1}$ & 1.86 & 2.73 & 1.27 & 0.11 & 0.35 & 0.64 & 0.56 & 0.89 \\
OSsoil $_{2}$ & 1.85 & 2.86 & 1.26 & 0.11 & 0.35 & 0.64 & 0.56 & 0.99 \\
OSsoil $_{3}$ & 1.59 & 1.94 & 1.26 & 0.86 & 0.39 & 0.69 & 0.56 & 0.95 \\
OSsed $_{1}$ & 1.85 & 2.69 & 1.29 & 0.11 & 0.35 & 0.63 & 0.56 & 0.88 \\
OSsed $_{2}$ & 3.36 & 6.02 & 1.18 & 0.09 & 0.23 & 0.70 & 0.54 & 0.63 \\
OSsed $_{3}$ & 1.80 & 2.82 & 1.28 & 0.10 & 0.36 & 0.63 & 0.56 & 0.89 \\
OSw $_{1}$ & 0.98 & 0.72 & 2.96 & 0.04 & 0.50 & 0.03 & 0.75 & 0.96 \\
OSw $_{2}$ & 1.15 & 0.61 & 1.40 & 0.04 & 0.47 & 0.34 & 0.58 & 0.80 \\
OSw $_{3}$ & 0.91 & 1.03 & 1.54 & 0.09 & 0.92 & 0.88 & 0.61 & 0.84
\end{tabular}

\section{Carcinogenic and Mutagenic Potency of PAHs}

The main concerns about the environmental contamination by PAHs are due to their health effect on human and other animals. Some of the polycyclic aromatic hydrocarbons are known human carcinogens and mutagens, Glower (1990) reported the mutagenic potential of Dibenzo(a,h)anthrancene, benzo(a)pyrene and benzo $(g, h, i)$ pyrene. The international Agency for research on cancer, IARC have also listed chyresene, benzo(a)anthracene, Dibenzo(a,h)anthrancene, benzo(a)pyrene, benzo(b)fluoroanthrene, benzo(k)flouoranthrane and indeo(1,2,3-cd)pyrene are potential human carcinogen (WHO, 1998, USEPA, 2012). All the listed carcinogenic and mutagenic PAHs are detected in the soil, water and sediment samples collected around the dumpsite. Table 7.0 shows the concentration of carcinogenic and mutagenic PAHs in the soil, water and sediment samples, the mean concentration of benzo(a)pyrene, a carcinogenic and mutagenic PAHs is highest in the soil sample $(9.92 \mu \mathrm{g} / \mathrm{Kg})$ and sediment $(3.15 \mu \mathrm{g} / \mathrm{Kg})$, the total mean concentration of carcinogenic PAHs in the soil, sediments and water samples are $10.72 \mu \mathrm{g} / \mathrm{Kg}$, $3.66 \mu \mathrm{g} / \mathrm{Kg}$ and $0.013 \mu \mathrm{g} / \mathrm{Kg}$ respectively. To assess the ecotoxicology risks at a particular site, the Benzo(a)pyrene-equivalent carcinogenicity and mutagenicity of the PAHs in the soil, sediments and water samples were calculated, the Bap-TEQ (carcinogenic equivalent) and Bap-MEQ (mutagenic equivalent) were calculated by multiplying the concentration of each PAHs compound with its TEF for cancer relative to Bap (Nisbet and LaGoy, 1992) 
Table 7.0: carcinogenic and mutagenic potency of PAHs in the soil, sediments and water samples

\begin{tabular}{|c|c|c|c|c|c|}
\hline PAHS & Mean concentration of carcinogenic PAHs $(\mathrm{mg} / \mathrm{kg})$ & TEF & $B[a] P-T P E$ & MEF & $B[a] P-M E Q$ \\
\hline & Soil sample & & & & \\
\hline Benzo(a)anthracene & 1.93 & 0.1 & 0.193 & 1.5826 & 1.5826 \\
\hline Chrysene & 1.53 & 0.01 & 0.015 & 0.02601 & 0.0260 \\
\hline Benzo(k)fluoranthene & 0.47 & 0.1 & 0.047 & 0.1175 & 0.1175 \\
\hline Benzo(b)fluoranthene & 0.70 & 0.1 & 0.070 & 0.077 & 0.0770 \\
\hline Benzo(a)pyrene & 9.92 & 1 & 9.920 & 9.92 & 9.9200 \\
\hline Indeno(1,2,3cd)pyrene & 1.75 & 0.1 & 0.175 & 0.5425 & 0.5425 \\
\hline Dibenzo(ah)anthracene & 0.62 & 5 & 3.100 & 0.1798 & 0.1798 \\
\hline Benzo(g,h,i)pyrene & 0.18 & 0.01 & 0.0018 & 0.0342 & 0.0342 \\
\hline$\Sigma C P A H$ & 16.92 & - & & & \\
\hline$\Sigma M P A H$ & 10.72 & & & & \\
\hline \multirow[t]{2}{*}{$\% \mathrm{CPAH}$} & 65 & & & & \\
\hline & Sediment sample & & & & \\
\hline Benzo(a)anthracene & 0.87 & 0.1 & 0.087 & 1.5826 & 0.7134 \\
\hline Chrysene & 0.69 & 0.01 & 0.007 & 0.02601 & 0.01173 \\
\hline Benzo(k)fluoranthene & 0.07 & 0.1 & 0.007 & 0.1175 & 0.0175 \\
\hline Benzo(b)fluoranthene & 0.03 & 0.1 & 0.003 & 0.077 & 0.0033 \\
\hline Benzo(a)pyrene & 3.15 & 1 & 3.150 & 9.92 & 3.15 \\
\hline Indeno $(1,2,3 c d)$ pyrene & 0.84 & 0.1 & 0.084 & 0.5425 & 0.2604 \\
\hline Dibenzo(ah)anthracene & 0.29 & 5 & 1.450 & 0.1798 & 0.0841 \\
\hline Benzo(g,h,i)pyrene & 0.23 & 0.01 & 0.0023 & 0.0342 & 0.0437 \\
\hline$\Sigma C P A H$ & 5.92 & & & & \\
\hline$\Sigma M P A H$ & 3.66 & & & & \\
\hline \multirow[t]{2}{*}{$\% \mathrm{CPAHS}$} & 15.83 & & & & \\
\hline & Water sample & & & & \\
\hline Benzo(a)anthracene & 0.83 & 0.1 & 0.083 & 1.5826 & 0.6806 \\
\hline Chrysene & 0.50 & 0.01 & 0.005 & 0.02601 & 0.0085 \\
\hline Benzo(k)fluoranthene & 0.07 & 0.1 & 0.007 & 0.1175 & 0.0175 \\
\hline Benzo(b)fluoranthene & 0.04 & 0.1 & 0.004 & 0.077 & 0.0044 \\
\hline Benzo(a)pyrene & 0.01 & 1 & 0.01 & 9.92 & 0.01 \\
\hline Indeno(1,2,3cd)pyrene & 0.01 & 0.1 & 0.001 & 0.5425 & 0.0031 \\
\hline Dibenzo(ah)anthracene & 0.001 & 5 & 0.005 & 0.1798 & 0.00029 \\
\hline Benzo(g,h,i)pyrene & 0.0004 & 0.01 & 0.000004 & 0.0342 & 0.000076 \\
\hline$\Sigma C P A H$ & 1.432 & & & & \\
\hline$\Sigma M P A H$ & 0.013 & & & & \\
\hline$\% C P A H S$ & 6.21 & & & & \\
\hline
\end{tabular}


and MEF relative to Bap (Busby et al., 1996; Durant et al., 1999). The Bap-MEQ and Bap-TEQ are shown in table 7.0. the Bap-TEQ and Bap$M E Q$ values for benzo(a)anthracene, dibenzo( $a, h)$ anthracene and Benzo(a)pyrene are the highest in the soil and sediments samples and are the most toxic when compared with other carcinogenic and mutagenic PAHs.

\section{Conclusion}

The results of the biochemical oxygen demand (BOD) and chemical oxygen demand (COD) of water samples, the $\mathrm{pH}$ and total organic carbon of all the samples showed that all the samples have some amount of carbonates, biodegradable and oxidizable pollutants and organic matter indicating pollution in the study area. The area under study is also moderately polluted based on the concentration of PAHs in the soil, sediment and water samples and potential source of PAHs contamination is pyrolytic, which result from majorly burning of refuse. The dumpsite constitutes a health risk for the people living within the vicinity of the dumpsite due to the accumulation of carcinogenic PAHs in the dumpsite soil which could leach to groundwater and runoff into nearby surface water bodies around the area. Therefore, it is recommended that an improved waste management system should be established.

\section{References}

Adedosu, T.A.,Adedosu, H.O., Sojinu, O.S. and Olajire, A.A. (2013).N- alkanes and Polycyclic Aromatic Hydrocarbons (PAH) Profile of Soil From Some Polluted Sites in Niger Delta, Nigeria. Journal of Environmental Earth Sciences 68(8):21392144.

Adekola, E.A., Salami, N and Lawai, S.O. 2003. Some trace elements determined in surface water and sediment of Oyunriver, Kwara State, Nigeria. European Journal of Scientific Research 74(2): 186-204
Amokaye, O.G. 2012. Environmental pollution and challenges of environmental governanace in Nigeria.British Journal of Arts and Social Sciences 10 (1) 203-220

Adeyemo, O.K. 2003.Consequence of pollution and degradation of Nigerian aquatic environment on fisheries resources. The Environmentalist 23: 297-306

Akan, J.C. andAbdulrahman F. I. (2008). Physico Chemical Determination of Pollutants in Waste Water and Vegetable Samples Along the Jakara Waste Water Channelling, Kano Metropolis, Kano State. European Journal of Scientific Research 23 (1) 122-133.

Arian, M.B., Kazi, T.G., Jamali, M.K., Afridi, H.I., Jalbani, $N$ and Shah, Q.A. 2008. Evaluation of physciochemical parameter and manchar lake and their composition with other global published values. Analytical Environmental Chemistry 9(2): 101-109.

DWAF (1996).South Africa Water Quality Guidelines 7: Aquatic Ecosystems (First Edition). Department of Water Affairs and Forestry, Pretoria.

Kruczynski W.M. (2002): Water Quality Concerns in the Florida Keys: Sources, effects and solutions. An Ecosystem Book. CRC Press, Boca Raton: pp827-881.

MCMichael, A.J. 2000. The urban environment and health in a world increasing globalization: issues for developing countries. Bulletin of the World Health Organization 78(9): 1117-1126.

Solomon K. R., Forget, J. Stermeroff, M.O. and Leary C., (2007). 'Persistent Organic Pollutants' '. United Nations environmental programme. http://www.chem unep.ch/pops/ritter/en/ritteren.

Sawyer C.C. and McCarty P.L (1978). Chemistry for Environmental Engineers.McGraw Hill. New York. pp. 331-514.

Stanković, D., Krstić, B. andNikolić, N. (2008).Effect of Traffic on the Soil 
Contamination with Polycyclic Aromatic Hydrocarbons (PAHs).Biotechnology \& Biotechnological Equipment:22(2) 736741.

Sojinu O. S, Wang J. Z, Sonibare O.O. and Zeng E. Y. (2010). Polycyclic Aromatic Hydrocarbons in Sediments and Soils from oil Exploration Areas of the Niger Delta, Nigeria. Journal of Hazardous Materials 174:641-647.
Sunnita, H. andSumajeet, K. (1999). Laboratory Manual for Environmental Chemistry.S. Chand and Company Limited. pp 47-99.

Walkley, A., Black, I.A. (1934). An examination of the Degtiareff method for determining organic carbon in soils: Effect of variations in digestion conditions and of inorganic soil constituents. Soil Science63: 251-263. 